The Israel Law Review has for over three decades been an indispensable tool for the English-speaking jurist interested in the principal developments of law in Israel. The Review contains articles on contemporary Israeli law, Jewish law, international law, comparative law and topics of general legal interest, as well as digests of major decisions laid down by the Israeli Supreme Court.

\title{
SPECIAL ISSUES
}

- Democracy and the Courts: Reprints of articles appearing in Vol. 32 on the perspectives on central developments in constitutionalism and their critiques in the U.S., Canada, Europe and Israel.
Vol. 32 (1998)
Price: US\$40/NIS 160

- Rights of the Accused, Crime Control and Protection of Victims: Papers examining the evidentiary and procedural aspects of the tension between effective protection from crime and the rights of the accused.
Vol. 31 (1997)
700 pages
Price: US\$45/NIS 180

- Reform of Criminal Law: A discussion on the proposed new Israeli Penal Code by renowned legal scholars from Israel and Germany, with an English translation of the new Law.
Vol. 30 (1996)
396 pages
Price: US $\$ 35 /$ NIS 140

- The Peace Process: A series of articles on a variety of aspects of the negotiations and agreements between the State of Israel, the PLO and Jordan, including the full text of all the major relevant documents.
Vol. 28 (1994)
370 pages
Price: US\$35/NIS 140

- Symposium on the RePort of the Commission of INQUiRy iNTo the Methods of INVESTIGATION OF THE GENERAL SECURITY SERVICE ReGARDING Hostile TERRORIST ACTIVTY: The Landau Commission Report.
Vol. 23 (1989)
265 pages
Price: US\$25/NIS 100

\section{COMPLETE SET}

Back issues from 1966-1998 (vols. 1-32): Special Price: US \$700/NIS 2800

\section{ANNUAL SUBSCRIPTION RATE}

Price: US \$42/NIS 175 (Additional charge for airmail delivery: US \$10)

Each volume (4 issues) contains approx. 700 pp. (please print in block letters)

Name

Address

All orders should be sent, with cheques, directly to:

THE ISRAEL LAW REVIEW ASSOCIATION, clo Faculty of Law,

Hebrew University, Mt. Scopus, P.O.B. 24100, Jerusalem 91240, Israel. 


\section{GLOSSARY}

Annotated Law Reports (A.L.R.)

Dinei Medinat Israel (Nusah

Hadash) (D.M.I.)

Divrei HaKnesset

HaPraklit

Hatza'ot Hok (H.H.)

Iton Rishmi (I.R.)

lyunei Mishpat

Kitvei Amana (K.A.)

Knesset

Kovetz HaTakanot (K.T.)

Laws of the State of Israel (L.S.I.)

Laws of the State of Israel

[New Version] (L.S.I.[N.V.])

Mehkarei Mishpat

Mishpat Umimshal

Mishpatim

Palestine Gazette (P.G.)

Palestine Law Reports (P.L.R.)

Piskei Din (Judgments) (P.D.)

Piskei Din Avoda (P.D.A.)

Piskei Din Ezrahiim (P.D.E.)

Piskei Din Rabbaniim (P.D.R.)

Psakim (Decisions)

Psakim Elyon (P.E.)

Psakim Mehoziim (P.M.)

Reshumot

Sefer HaHukim (S.H.)

Selected Judgments (S.J.)

Yalkut HaPirsumim (Y.P.)
- Published in Palestine (1943-47)

- Revised, updated and binding Hebrew text of pre-State legislation

- Records of Knesset proceedings

- Law Journal published by the Israel Bar Association

- Legislative Bills

- Official Gazette during the tenure of the Provisional Council of State

- Tel Aviv University Law Review

- Israel Treaty Documents

- Israel Legislative Assembly

- Subsidiary Legislation

- Authorized English translation of Israeli legislation

- Authorized English edition of revised text of pre-State legislation

- Bar llan University Law Review

- Haifa University Law Review

- Student Law Review, Faculty of Law, Hebrew University of Jerusalem

- Official Gazette during the Mandatory Government

- Published in Palestine (1920-47)

- Law reports of the Supreme Court (1948-

- Law reports of the Labour Courts (1969-

- Law reports of the Income Tax Commission

- Selected law reports of the Rabbinical Courts

- Law reports of the Supreme Court and District Courts, published privately (1948)

- Law reports of the Supreme Court, published by the Israel Bar Association (1948-1961)

- Law reports of the District Courts (1949-

- Official Gazette since the inception of the Knesset

- Principal Legislation

- English translation of Selected Judgments of the Supreme Court of Israel (1948-

- Government Notices 